\title{
ANALISA PENGUJIAN SISTEM INFORMASI RUMAH SAKIT (STUDI KASUS RUMAH SAKIT KHUSUS BEDAH AN NUR YOGYAKARTA)
}

\author{
Ulinnuha Yudiansa Putra \\ Universitas Ahmad Dahlan
}

\begin{abstract}
Information technology system can be used to facilitate data processing companies, speeding up transaction processing to be used as a managerial decisionmaking. An information technology system can be said to be successful or suitable for use by the firms if they meet certain factors. DeLone and McLean (2003) has provided an overview of the factors that can be used to assess whether an appropriate information system has been used in a company. Factors used in this study is the Quality Systems, Information Quality, Service Quality, User Satisfaction and Net Benefits. This research was conducted at the Hospital for Special Surgery AN NUR Yogyakarta. The object that is used is SIMRS (Hospital Management Information System) used by respondents are 50 employees who use SIMRS Hospital in support of the work. The analytical tool used in this study is to Partial Least Square (PLS). The results showed that the quality of information, quality of service and user satisfaction significantly influence the net benefits while not affecting the quality system net benefits.

Keywords: information technology systems, DeLone and McLean Model, Partial Least Square, quality systems, information quality, service quality, user satisfaction, net benefits
\end{abstract}

\footnotetext{
PENDAHULUAN

Kemajuan teknologi informasi telah banyak dimanfaatkan oleh perusahaan untuk mengolah informasi untuk berbagai macam tujuan mulai dari otomatisasi perusahaan yang tujuannya adalah untuk mempermudah serta mempercepat pengolahan dan komunikasi data, sistem pemrosesan transaksi sampai pada penggunaan sistem untuk decision making.

Gambaran mengenai perkembangan teknologi informasi dapat dijelaskan bahwa suatu sistem informasi berfungsi sebagai pemegang peranan sentral dan vital dalam menghasilkan informasi secara cepat, tepat dan efisien. Alasannya adalah suatu sistem teknologi
}

informasi sangat dibutuhkan bagi perusahaan untuk tetap bersaing dan untuk meningkatkan produktivitas perusahaan, selain itu juga dapat meningkatkan efisiensi dan efektifitas kegiatan operasi perusahaan sehingga dapat meningkatkan daya saing suatu perusahaan. Penggunaan sistem teknologi informasi merupakan suatu investasi yang mahal bagi suatu perusahaan / organisasi. Walaupun dengan investasi yang mahal tersebut tidak dapat dipastikan bahwa sistem tersebut berkualitas dan sesuai dengan kebutuhan / harapan dari perusahaan. Penelitian yang dilakukan oleh Robbins dalam Wiyono dkk (2008) menyatakan bahwa survei yang dilakukan oleh lembaga penelitian terhadap 232 responden di Amerika atas implementasi ERP pada tempat 
mereka bekerja menunjukkan bahwa 51\% melihat implementasi ERP tidak berhasil dan $46 \%$ lainnya merasa perusahaan mereka tidak memahami bagaimana menggunakan sistem teknologi informasi untuk mengembangkan diri dalam menjalankan bisnis. Berdasarkan penelitian tersebut dapat diambil kesimpulan bahwa keberhasilan implementasi sistem teknologi informasi dipengaruhi oleh beberapa faktor yang komplek sedangkan kegagalan implementasi sistem teknologi informasi biasanya terjadi karena tidak kompatibelnya sistem dengan proses bisnis dan informasi yang dibutuhkan oleh perusahaan (Janson dan Subramanian 1996; Lucas et al. 1988 dalam Budianto 2010)

Penelitian menggunakan sistem informasi yang berada di Rumah Sakit Khusus Bedah AN NUR. Bentuk sistem informasi yang digunakan adalah ERP dimana sistem tersebut saling terintegrasi di setiap unit / bagian pelayanan di rumah sakit. Fungsi dari sistem informasi di rumah sakit adalah untuk mempercepat pelayanan non medis yang diberikan kepada setiap pasien terkait dengan billing system. Diharapkan dengan sistem tersebut pasien tidak perlu menunggu lama untuk dapat mengetahui berapa biaya yang ditagihkan. Penelitian ini dilakukan di Rumah Sakit Khusus Bedah AN NUR Yogyakarta yang telah menggunakan sebuah sistem yang dinamakan SIMRS (Sistem Informasi Manajemen Rumah Sakit).

Berbagai permasalahan pada saat SIMRS berjalan antara lain belum optimalnya modul yang ada di pelayanan rawat inap. Kemudian kondisi server yang dirasa belum optimal dikarenakan sering terjadi gangguan yang menyebabkan sistem mati. Salah satu penyebab server sering mengalami gangguan adalah karena tidak termonitornya server oleh petugas IT yang ada di Rumah Sakit. Selain itu juga, hasil cetakan (print out) dari SIMRS yang belum maksimal karena masih sering terdapat garis yang terpotong maupun yang tidak teratur
Berdasarkan permasalahan inilah yang menarik minat peneliti untuk menguji dan menganalisis implementasi Sistem Informasi Manajemen Rumah Sakit (SIMRS) yang dikembangkan oleh Rumah Sakit AN NUR Yogyakarta dengan menggunakan model kesuksesan sistem informasi yang dikembangkan oleh DeLone dan McLean (2003). Perbedaan dengan penelitian model DeLone dan McLean (2003) yang lain adalah bahwa penelitian ini tidak menggunakan variabel intensitas penggunaan (intention of use) dengan alasan bahwa sistem informasi yang digunakan oleh Rumah Sakit memiliki sifat mandatory (wajib digunakan) oleh seluruh karyawan.

Atas dasar landasan berfikir diatas, maka permasalahan yang dapat dikembangkan adalah:

1. Apakah kualitas sistem (system quality) berpengaruh positif terhadap kepuasan pemakai (users satisfaction)

2. Apakah kualitas informasi (information quality) berpengaruh positif terhadap kepuasan pemakai (users satisfaction)

3. Apakah kualitas pelayanan (service quality) berpengaruh positif terhadap kepuasan pemakai (users satisfaction)

4. Apakah kepuasan pemakai (users satisfaction) berpengaruh positif terhadap manfaat-manfaat bersih (Net Income)

\section{REVIEW LITERATUR DAN HIPOTESIS}

\section{Kesuksesan Sistem Informasi}

Model kesuksesan sistem informasi DeLone and McLean (1992) merupakan suatu penelitian yang pertama kali mengintegrasikan gambaran mengenai konsep kesuksesan sistem informasi. Model ini menggabungkan 6 dimensi kesuksesan sistem informasi yaitu: kualitas sistem (system quality), kualitas informasi (information system), penggunaan (use), kepuasan pemakai (user satisfaction), dampak individual (individual impact), dan dampak organisasi (organizational impact). 
Model ini tidak mengukur ke enam dimensi pengukuran kesuksesan sistem informasi secara independen tetapi mengukurnya secara keseluruhan satu mempengaruhi yang lainnya. Model ini didasarkan pada proses dimana suatu sistem terdiri dari beberapa proses yaitu satu proses mengikuti proses yang lainnya. Berbeda dengan model proses, model kausal atau disebut juga dengan model varian (variance model) berusaha untuk menjelaskan kovarian dari elemen-elemen model untuk menentukan apakah variansi dari satu elemen dapat dijelaskan oleh variansi dari elemen-elemen lainnya atau dengan kata lain untuk menentukan apakah terjadi hubungan kausal diantara mereka.

Hammer (2004) melakukan penelitian mengenai implementasi sistem informasi rumah sakit terkomputerisasi (computerised hospital information system) pada suatu rumah sakit pemerintah di Afrika Selatan. Kesimpulan dari penelitian ini adalah kualitas sistem berpengaruh terhadap penggunaan sedangkan kualitas informasi memberikan pengaruh yang lemah terhadap kepuasan pemakai. Radityo dan Zulaikha (2007) melakukan penelitian untuk menguji implementasi penggunaan aplikasi SIMAWEB (Sistem Informasi Akademik Berbasis Website) di Fakultas Ekonomi Universitas Diponegoro. Kesimpulan dari penelitian ini adalah kualitas sistem tidak berpengaruh secara signifikan terhadap penggunaan, kualitas sistem tidak memiliki pengaruh signifikan terhadap kepuasan pemakai, kualitas informasi tidak memiliki pengaruh signifikan terhadap penggunaan, kualitas informasi tidak berpengaruh signifikan terhadap kepuasan pemakai sementara penggunaan dan kepuasan pemakai tidak terbukti saling mempengaruhi satu dengan lainnya.

\section{Pengembangan Model Kesuksesan Sistem Informasi DeLone dan McLean (2003)}

Latar belakang munculnya Model Kesuksesan Sistem Informasi DeLone and McLean
(2003) adalah adanya kritikan yang disampaikan oleh Peter B. Seddon (1997) mengenai model DeLone and McLean yang mencampur antara model proses dan model varian. Kritikan yang lainnya adalah mengenai penggunaan variabel pemakaian sistem (system use).

Berdasarkan kritikan-kritikan tersebut maka DeLone and McLean mencoba memperbaharui model kesuksesan sistem informasi dengan beberapa catatan diantaranya adalah:

1. Menambah dimensi kualitas pelayanan (service quality) sebagai tambahan dari dimensi-dimensi kualitas yang sudah ada, yaitu kualitas sistem (system quality) dan kualitas informasi (information quality).

2. Menggabungkan dampak individual (individual impact) dan dampak organisasional (organizational impact) menjadi satu variabel yaitu manfaat-manfaat bersih (net benefits). Alasan terjadinya penggabungan adalah dampak dari sistem informasi yang dipandang sudah meningkat tidak hanya dampaknya pada pemakai individual dan organisasi saja, tetapi dampaknya sudah ke grup pemakai, ke antar organisasi, konsumer, pemasok, sosial bahkan ke negara. Tujuan penggabungan ini adalah untuk menjaga model tetap sederhana (parsimony).

3. Menambahkan dimensi minat memakai (intention to use) sebagai alternatif dari dimensi pemakaian (use). DeLone \& McLean (2003) mengusulkan pengukuran alternatif, yaitu minat memakai (intention to use). Minat memakai adalah suatu sikap (attitude), sedang pemakaian (use) adalah suatu perilaku (behavior). DeLone \& McLean (2003) juga berargumentasi dengan mengganti pemakaian (use) memecahkan masalah yang dikritik oleh Seddon (1997) tentang model proses lawan model kausal.

Banyak penelitian yang telah dilakukan 
dengan menggunakan model DeLone and McLean yang telah diperbaharui (2003). Budianto (2009) yang meneliti mengenai implementasi sistem informasi rumah sakit terkomputerisasi (computerised hospital information system) di Rumah Sakit Umum Daerah Kabupaten Sragen dengan mengambil objek billing system. Penelitian ini menggunakan 8 hipotesis yang hasilnya 5 hipotesis dinyatakan diterima dan 3 hipotesis lainnya ditolak.

\section{Hipotesis}

Penelitian mengenai SIMRS ini menggunakan model DeLone dan McLean yang telah diperbaharui (2003). Adapun variabel / konstruk yang terdapat dalam model DeLone dan McLean adalah kualitas sistem (system quality), kualitas informasi (information quality), kualitas pelayanan (service quality), intensitas penggunaan (intention of use), kepuasan pemakai (costumer satisfaction) dan manfaat-manfaat bersih (net benefit). Penelitian ini mengadopsi dari hasil penelitian yang dilakukan oleh Livari (2005) dimana menghilangkan salah satu variabel yaitu intensitas penggunaan (intention of use). Alasannya adalah karena objek penelitian adalah sistem yang memiliki sifat mandatory (wajib digunakan) sehingga kurang cocok dengan rencana penelitian yang akan dilakukan sehingga model yang penelitian ini adalah sebagai berikut :

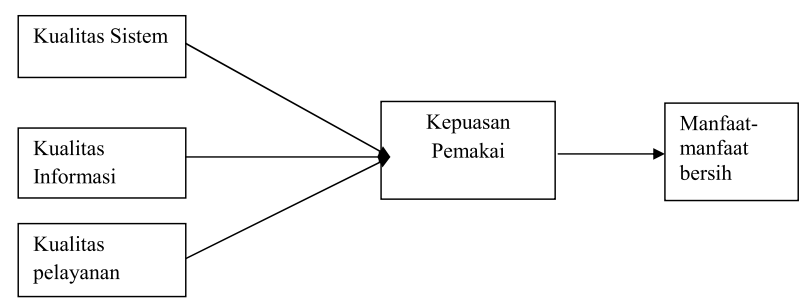

\section{Gambar 1 Model Penelitian}

Berdasarkan model penelitian di atas dapat dihasilkan suatu hipotesis penelitian, yaitu:
$\mathrm{H}_{1}$ : Kualitas sistem berpengaruh positif terhadap kepuasan pemakai

$\mathrm{H}_{2}$ : Kualitas informasi berpengaruh positif terhadap kepuasan pemakai

$\mathrm{H}_{3}$ : Kualitas pelayanan berpengaruh positif terhadap kepuasan pemakai

$\mathrm{H}_{4}$ : Kepuasan pemakai berpengaruh positif terhadap manfaat-manfaat bersih

\section{METODE PENELITIAN}

Penelitian ini adalah penelitian yang bersifat induktif. Tujuan dari penelitian ini adalah untuk menguji hipotesis terkait penerapan sistem informasi manajemen rumah sakit di Rumah Sakit Khusus Bedah AN NUR dengan menggunakan model DeLone dan McLean yang telah diperbarui (2003).

Objek yang diteliti adalah pemakai sistem informasi khususnya pemakai mandatory (mandatory users). Pemakai sistem informasi mandatory dalam hal ini adalah individu yang menggunakan sistem informasi bukan atas kemauannya sendiri tetapi karena memang tuntutan atau kewajiban dari kerja. Data yang digunakan dalam penelitian ini adalah data primer dengan sistem informasi di Rumah Sakit Khusus Bedah AN NUR sebagai objek penelitian. Data primer merupakan data dan informasi yang diperoleh melalui wawancara dengan pihak manajemen dan karyawan RSKB AN NUR dan pengumpulan kuesioner yang diberikan kepada karyawan yang secara langsung menggunakan sistem informasi berbasis SIMRS.

Kuesioner yang diberikan kepada responden / karyawan berupa kuesioner tertutup yang artinya adalah setiap pernyataan yang ada responden diminta untuk menjawab dengan jawaban yang sudah disediakan yang dalam hal ini responden diminta untuk memilih salah satu jawaban yang sesuai dengan keadaan dirinya. Kuesioner ini berisi tentang pertanyaan dari indikator-indikator penelitian yang muatan rin- 
cian pernyataannya didasarkan pada penjelasan konstruk yaitu kualitas sistem, kualitas informasi, kualitas pelayanan, kepuasan pemakai, dan manfaat-manfaat bersih dilihat secara individual, grup / unit kerja, maupun organisasional.

Metode penentuan sampel yang digunakan dalam penelitian ini adalah dengan metode purposive sampling. Adapun jumlah populasi di Rumah Sakit Khusus Bedah AN NUR adalah sebanyak 80 orang dan yang dijadikan sampel dalam penelitian ini adalah 50 orang yang diperoleh dari seluruh karyawan yang berada di tiap unit - unit pelayanan yang berhubungan langsung terhadap pasien dan menggunakan sistem informasi secara mandatory yaitu seperti Pendaftaran (front office), Rekam Medis, Rawat Jalan, Rawat Inap, IGD, Laboratorium, Radiologi, Farmasi / Apotek dan Keuangan.

Variabel-variabel yang digunakan dalam penelitian ini terdiri dari variable independen (X) dan variabel dependen (Y). Variabel-variabel tersebut diukur dengan menggunakan skala Likert 7 point. Adapun variabel independen yang digunakan dalam penelitian ini adalah:

\section{Kualitas Sistem}

Kualitas sistem berarti kualitas dari kombinasi hardware dan software dalam sistem informasi. Fokusnya adalah performa dari sistem, yang merujuk pada seberapa baik kemampuan perangkat keras, perangkat lunak, kebijakan, prosedur dari sistem informasi yang menyediakan informasi sesuai kebutuhan pengguna (DeLone dan McLean, 1992).

\section{Kualitas Informasi}

Kualitas Informasi (Information Quality) merujuk pada output dari sistem informasi menyangkut nilai, manfaat, relevansi dan urgensi dari informasi yang dihasilkan (Pitt dan Watson, 1995). Sama dengan kualitas sistem, kualitas informasi diukur secara subjektif oleh pemakai yang selanjutnya disebut sebagai kualitas informasi persepsian (perceived information quality).

\section{Kualitas Pelayanan}

Pengukuran kualitas pelayanan (service quality) awalnya digunakan di penelitian pemasaran (marketing). Penelitian-penelitian sistem informasi yang memasukkan pengukuran kualitas pelayanan ke dalam model D\&M hanya meminjam dari penelitian pemasaran. Sebenarnya kualitas pelayanan (service quality) merupakan bagian dari kualitas sistem (system quality). Akan tetapi seiring dengan perkembangan perubahan peran pemakai akhir dan perubahan peran sistem teknologi informasi yang menjadi peran strategik menyebabkan tuntutan untuk memisahkan pengukuran kualitas pelayanan (service quality) dari kualitas sistem (system quality).

\section{Kepuasan Pemakai}

Kepuasan pengguna sistem (user satisfaction) merupakan respon dan umpan balik yang dimunculkan pengguna setelah memakai sistem informasi. Sikap pengguna terhadap sistem informasi merupakan kriteria subjektif mengenai seberapa suka pengguna terhadap sistem yang digunakan.

\section{Manfaat-manfaat bersih}

Dampak dari sistem informasi sudah meningkat tidak hanya dampaknya pada pemakai individual dan organisasi saja, tetapi dampaknya sudah ke grup pemakai, ke antar organisasi, konsumer, pemasok, sosial bahkan ke negara.

\section{Metode Analisis Data}

Penelitian ini menggunakan model persamaan struktural (structural equation model atau $S E M)$ dalam pengujian modelnya. SEM memiliki fleksibilitas yang lebih tinggi bagi peneliti untuk menghubungkan teori dan data. SEM diklasifikasikan menjadi dua, yaitu SEM berbasis covariance dan SEM berbasis varian. Penelitian 
ini akan menggunakan SEM berbasis varian yaitu dengan menggunakan partial least square (PLS). Kelebihan menggunakan PLS adalah karena PLS merupakan metode analisis yang powerfull karena tidak didasarkan pada banyak asumsi. PLS juga tepat digunakan dalam model yang dasar teorinya tidak begitu kuat dengan melibatkan banyak konstruk.

Evaluasi dalam model PLS dilakukan dengan mengevaluasi outer model dan inner model.Outermodelmerupakan model pengukuran untuk menilai validitas dan realibilitas model. Melalui proses interasi algoritma, parameter model pengukuran (validitas konvergen, validitas diskriminan, composite realibility dan cronbach's alpha) diperoleh, termasuk nilai $\mathrm{R}^{2}$ sebagai parameter ketepatan model prediksi, sedangkan inner model merupakan model struktural untuk memprediksi hubungan kausalitas antar variabel laten. Melalui proses bootstraping, parameter uji T-Statistic diperoleh untuk memprediksi adanya hubungan kausalitas (Jogiyanto, 2009).

\section{HASIL PENELITIAN DAN PEMBAHASAN}

Penelitian ini dilakukan dengan menyebarkan kuesioner kepada para karyawan sebanyak 50 eksemplar dan yang diterima kembali berjumlah 50 eksemplar dengan tingkat respon sebesar $100 \%$. Dalam penelitian ini usia responden dikelompokkan menjadi 4 interval. Berdasarkan pengelompokan tersebut ternyata pada usia antara 25 tahun sampai 30 tahun mendominasi sebagian besar responden dalam penelitian ini. Sedangkan kelompok responden paling sedikit adalah yang berusia dibawah 20 tahun. Komposisi masing-masing kelompok usia, ditunjukkan pada tabel dibawah ini:
Tabel 1

Profil Responden Berdasarkan Kelompok

Usia

\begin{tabular}{|c|c|c|}
\hline Umur & $\begin{array}{l}\text { Jumlah } \\
\text { Responden } \\
\text { (orang) }\end{array}$ & Prosentase ( \% ) \\
\hline$<19$ tahun & 2 orang & $4 \%$ \\
\hline 20 tahun -29 tahun & 40 orang & $80 \%$ \\
\hline 30 tahun -39 tahun & 5 orang & $10 \%$ \\
\hline$>40$ tahun & 3 orang & $6 \%$ \\
\hline Jumlah & 50 orang & $100 \%$ \\
\hline
\end{tabular}

Sumber : hasil olah data

Berdasarkan data diatas memperlihatkan bahwa pemakai SIMRS dilakukan oleh karyawan dengan usia paling produktif yaitu 20 tahun - 29 tahun sebesar $80 \%$. Hal ini dapat menunjukkan bahwa manajemen berusaha memberikan perhatian yang khusus menyangkut pengoperasian SIMRS agar dilakukan secara lebih baik dan optimal dengan menyerahkan tanggungjawab pengoperasiannya kepada karyawan dengan usia paling produktif.

Berdasarkan gender, jumlah responden dalam penelitian ini didominasi oleh perempuan sebagaimana ditunjukkan dalam tabel dibawah ini. Hal ini dapat dipahami karena pemakai SIMRS Rumah Sakit Khusus Bedah AN NUR merupakan sektor yang bergerak di bidang jasa dimana banyak digeluti oleh perempuan.

Tabel 2

Profil Responden Berdasarkan Jenis Kelamin \begin{tabular}{|c|c|c|}
\hline Jenis Kelamin & $\begin{array}{c}\text { Jumlah Responden } \\
\text { (orang) }\end{array}$ & Prosentase (\% ) \\
\hline Laki-laki & 23 orang & $46 \%$ \\
\hline Perempuan & 27 orang & $54 \%$ \\
\hline Jumlah & 50 orang & $100 \%$ \\
\hline
\end{tabular}

Sumber : hasil olah data

Berdasarkan tingkat pendidikan, responden yang paling banyak mengoperasikan SIMRS dalam penelitian ini adalah responden yang berpendidikan Diploma yakni sebesar 32 orang atau 64\% dari total responden. Responden yang berpendidikan S1 (Sarjana) sebanyak 7 orang atau 
$14 \%$, dan yang berpendidikan SLTA sebanyak 10 orang atau $20 \%$ dari total responden. Sedangkan responden yang berpendidikan selain yang termasuk diatas hanya sebanyak 1 orang dengan nilai prosentasenya sebanyak $2 \%$. Adapun rincian data responden berdasarkan pendidikan dapat dilihat pada tabel dibawah ini

\section{Tabel 3}

Profil Responden Berdasarkan Pendidikan

\begin{tabular}{|c|c|c|}
\hline Pendidikan & $\begin{array}{c}\text { Jumlah } \\
\text { Responden } \\
\text { (orang) }\end{array}$ & Prosentase (\%) \\
\hline SLTA & 10 orang & $64 \%$ \\
\hline Diploma & 32 orang & $14 \%$ \\
\hline Sarjana & 7 orang & $20 \%$ \\
\hline Lainnya & 1 orang & $2 \%$ \\
\hline Jumlah & 50 orang & \\
\hline
\end{tabular}

Sumber : hasil olah data

Berdasarkan unit kerja tabel dibawah ini dapat menunjukkan bahwa jumlah responden yang berkaitan langsung atas implementasi SIMRS di Rumah Sakit Khusus Bedah AN NUR Yogyakarta ini terdiri atas beberapa bagian. Responden yang paling banyak berdasarkan bagian / unit kerja yang menggunakan SIMRS adalah bagian Rawat Inap dimana jumlah responden yang berada dalam unit tersebut adalah sebanyak 16 responden atau $32 \%$ dari jumlah responden. Sedangkan untuk jumlah responden yang paling sedikit berdasarkan bagian/unit kerja adalah bagian Rawat Jalan dan bagian Rekam Medis dimana masing-masing responden yang berada di bagian tersebut hanya berjumlah 2 responden atau 4\% dari jumlah responden. Hal tersebut cukup beralasan karena Rumah Sakit Khusus Bedah AN NUR ini lebih menekankan pada perawatan Rawat Inap sehingga responden yang berada di bagian Rawat Inap lebih banyak dari bagian-bagian lain.

\section{Tabel 4}

Profil Responden Berdasarkan Unit Kerja

Karyawan

\begin{tabular}{|c|c|c|}
\hline Bagian / Unit Kerja & $\begin{array}{c}\text { Jumlah } \\
\text { Responden } \\
\text { (orang) }\end{array}$ & $\begin{array}{c}\text { Prosentase } \\
(\%)\end{array}$ \\
\hline Farmasi / Apotek & 8 orang & $16 \%$ \\
\hline IGD & 4 orang & $8 \%$ \\
\hline Keuangan & 5 orang & $10 \%$ \\
\hline Laboratorium & 5 orang & $10 \%$ \\
\hline Pendaftaran & 3 orang & $6 \%$ \\
\hline Radiologi & 5 orang & $10 \%$ \\
\hline Rawat Jalan & 2 orang & $4 \%$ \\
\hline Rawat Inap & 16 orang & $32 \%$ \\
\hline Rekam Medis & 2 orang & $4 \%$ \\
\hline Jumlah & 50 orang & $100 \%$ \\
\hline
\end{tabular}

\section{Sumber : hasil olah data}

\section{Uji Validitas}

Uji validitas dilakukan untuk mengetahui kemampuan instrumen penelitian mengukur apa yang seharusnya diukur (Cooper dan Schindler, 2006). Uji validitas terdiri atas validitas eksternal dan validitas internal. Dalam validitas internal terdiri atas validitas kualitatif dan validitas konstruk. Validitas konstruk menunjukkan seberapa baik hasil yang diperoleh dari penggunaan suatu pengukuran sesuai teori-teori yang digunakan untuk mendefinisikan suatu konstruk. Korelasi yang kuat antara konstruk dan item-item pertanyaannya dan hubungan yang lemah dengan variabel lainnya merupakan salah satu cara untuk menguji validitas konstruk (construct validity). Validitas konstruk terdiri atas validitas konvergen dan validitas diskriminan.

Covergent validity dari model pengukuran dengan reflektif indikator dinilai berdasarkan korelasi antara item score / component score dengan construct score yang dihitung dengan PLS. Ukuran refleksif individual dikatakan tinggi jika berkorelasi lebih dari 0.70 dengan konstruk yang ingin diukur. Namun demikian untuk penelitian tahap awal dari pengembangan skala pengukuran nilai loading 0,5 sampai 0.6 dianggap cukup (Chin, 1998).

Discriminant validity dari model pengukuran dengan reflektif indikator dinilai dengan 
membandingkan nilai square root of average variance extracted (AVE) setiap konstruk dengan korelasi antara konstruk dengan konstruk lainnya dalam model. Jika nilai akar kuadrat AVE setiap konstruk lebih besar daripada nilai korelasi antara konstruk dengan konstruk lainnya dalam model, maka dikatakan memiliki nilai discriminant validity yang baik (Fornell dan Larcker, 1981)

Tabel 5

Uji Convergent Validity dan Discriminant Validity

\begin{tabular}{|c|c|c|c|c|c|}
\hline & Kul_Sis & Kul_Inf & Kul_Pel & Kep_Pem & Net Benefit \\
\hline KI1 & 0.758 & 0.866 & 0.696 & 0.746 & 0.910 \\
\hline KI2 & 0.570 & 0.862 & 0.464 & 0.501 & 0.773 \\
\hline KI3 & 0.771 & 0.920 & 0.737 & 0.616 & 1.019 \\
\hline KI4 & 0.900 & 0.910 & 0.881 & 0.810 & 1.044 \\
\hline KI5 & 0.456 & 0.728 & 0.513 & 0.358 & 0.637 \\
\hline KI6 & 0.466 & 0.795 & 0.486 & 0.323 & 0.622 \\
\hline KP1 & 0.407 & 0.473 & 0.777 & 0.287 & 0.443 \\
\hline KP2 & 0.658 & 0.755 & 0.899 & 0.617 & 0.819 \\
\hline KP3 & 0.380 & 0.639 & 0.518 & 0.287 & 0.704 \\
\hline KP4 & 0.464 & 0.533 & 0.851 & 0.490 & 0.628 \\
\hline KS1 & 0.820 & 0.683 & 0.585 & 0.531 & 0.797 \\
\hline KS2 & 0.797 & 0.847 & 0.618 & 0.592 & 0.783 \\
\hline KS3 & 0.773 & 0.606 & 0.480 & 0.406 & 0.518 \\
\hline KS4 & 0.803 & 0.648 & 0.464 & 0.319 & 0.648 \\
\hline KS5 & 0.592 & 0.432 & 0.409 & 0.236 & 0.685 \\
\hline KS6 & 0.809 & 0.759 & 0.678 & 0.527 & 0.570 \\
\hline KS7 & 0.746 & 0.542 & 0.442 & 0.318 & 0.666 \\
\hline NB1 & 0.491 & 0.597 & 0.574 & 0.456 & 0.864 \\
\hline NB10 & 0.115 & 0.098 & 0.179 & 0.063 & 0.322 \\
\hline NB2 & 0.574 & 0.704 & 0.621 & 0.519 & 0.876 \\
\hline NB3 & 0.516 & 0.634 & 0.493 & 0.415 & 0.834 \\
\hline NB4 & 0.406 & 0.493 & 0.386 & 0.224 & 0.762 \\
\hline NB5 & 0.418 & 0.568 & 0.414 & 0.260 & 0.770 \\
\hline NB6 & 0.419 & 0.552 & 0.358 & 0.296 & 0.858 \\
\hline NB7 & 0.291 & 0.381 & 0.275 & 0.207 & 0.768 \\
\hline NB8 & 0.329 & 0.427 & 0.353 & 0.310 & 0.488 \\
\hline NB9 & 0.111 & 0.090 & 0.099 & -0.002 & 0.345 \\
\hline US1 & 0.788 & 0.987 & 0.874 & 0.957 & 1.004 \\
\hline US2 & 0.752 & 1.000 & 0.870 & 0.966 & 0.965 \\
\hline US3 & 0.804 & 1.061 & 0.867 & 0.952 & 0.929 \\
\hline
\end{tabular}

Sumber : hasil olah data
Berdasarkan tabel pengujian convergent validity dapat dilihat bahwa semua loading factor nilainya diatas 0,7 dan terdapat 5 indikator yang mempunyai nilai loading factor di bawah 0,7 yaitu indikator konstruk Kualitas Sistem, Kualitas Pelayanan dan Net Benefit. Secara keseluruhan dapat disimpulkan bahwa konstruk mempunyai convergent validity yang baik.

Tabel 6

Akar AVE dan korelasi antar konstruk

\begin{tabular}{|c|c|c|c|c|c|}
\hline & Kep_Sis & Kul_Inf & Kul_Pel & Kep_Pem & Net Benefit \\
\hline Kep_Sis & $\mathbf{1 . 0 0 0}$ & & & & \\
\hline Kul_Inf & 0.896 & $\mathbf{1 . 0 0 0}$ & & & \\
\hline Kul_Pel & 0.849 & 0.787 & $\mathbf{1 . 0 0 0}$ & & \\
\hline Kep_Pem & 0.775 & 0.786 & 0.787 & $\mathbf{1 . 0 0 0}$ & \\
\hline $\begin{array}{c}\text { Net } \\
\text { Benefit }\end{array}$ & 0.754 & 0.739 & 0.697 & 0.608 & $\mathbf{1 . 0 0 0}$ \\
\hline
\end{tabular}

Sumber : hasil olah data

Berdasarkan tabel diatas ini telah jelas bahwa nilai akar AVE lebih tinggi dibandingkan dengan nilai korelasi antara konstruk lainnya dan secara keseluruhan dapat disimpulkan bahwa konstruk tersebut memiliki nilai discriminant validity yang tinggi.

\section{Uji Realibilitas}

Selain uji validitas, PLS juga melakukan uji realibilitas Uji realibilitas dalam PLS menggunakan dua metode, yaitu Cronbach's Alpha dan Composite Reliability. Cronbach's Alpha mengukur batas bawah nilai realibilitas suatu konstruk sedangkan Composite Reliability mengukur nilai sesungguhnya realibilitas suatu konstruk (Chin dan Gopal, 1995 dalam Salisbury et al. 2002). 
Tabel 7

Composite Realibility dan AVE

\begin{tabular}{|c|c|c|}
\hline & $\begin{array}{c}\text { Composite } \\
\text { Reliability }\end{array}$ & $\begin{array}{c}\text { Average variance extracted } \\
\text { (AVE) }\end{array}$ \\
\hline Kep_Sis & 0.908 & 0.587 \\
\hline Kul_Inf & 0.939 & 0.722 \\
\hline Kul_Pel & 0.853 & 0.601 \\
\hline Kep_Pem & 0.971 & 0.919 \\
\hline Net Benefit & 0.940 & 0.690 \\
\hline
\end{tabular}

Sumber: hasil olah data

Karena nilai composite realibility diatas 0,70 dan nilai AVE diatas 0,50. dapat disimpulkan bahwa semua konstruk memenuhi realibilitas (baik).Model pengukuran atau outermodel dengan indikator refleksif dievaluasi dengan convergent dan discriminant validity dari indikatornya dan composite reliability untuk block indikator. Stabilitas dari estimasi ini dievaluasi dengan menggunakan uji t-statistik yang diperoleh lewat prosedur bootstraping. Indikator-indikator atau konstruk dianggap memiliki validitas yang baik jika nilai masing-masing indikator signifikan terhadap nilai Convergent validity atau nilai loading factor sebesar 0.70. Namun demikian pada riset tahap pengembangan skala, loading 0,50 sampai 0,60 masih dapat diterima.
Tabel 8

Result for Outer Loading

\begin{tabular}{|c|c|c|c|c|}
\hline & $\begin{array}{l}\text { original } \\
\text { sample } \\
\text { estimate }\end{array}$ & $\begin{array}{c}\text { mean of } \\
\text { subsamples }\end{array}$ & $\begin{array}{l}\text { Standard } \\
\text { deviation }\end{array}$ & T-Statistic \\
\hline \multicolumn{5}{|l|}{ Kep_Sis } \\
\hline KS1 & 0.820 & 0.807 & 0.057 & 14.293 \\
\hline KS2 & 0.797 & 0.785 & 0.060 & 13.383 \\
\hline $\mathrm{KS} 3$ & 0.773 & 0.764 & 0.063 & 12.235 \\
\hline KS4 & 0.803 & 0.778 & 0.067 & 12.008 \\
\hline KS5 & 0.592 & 0.596 & 0.160 & 3.710 \\
\hline KS6 & 0.809 & 0.797 & 0.067 & 12.006 \\
\hline KS7 & 0.746 & 0.737 & 0.092 & 8.094 \\
\hline \multicolumn{5}{|l|}{ Kul_Inf } \\
\hline KI1 & 0.866 & 0.863 & 0.022 & 40.250 \\
\hline $\mathrm{KI} 2$ & 0.862 & 0.851 & 0.047 & 18.408 \\
\hline $\mathrm{KI} 3$ & 0.920 & 0.916 & 0.021 & 43.115 \\
\hline $\mathrm{KI} 4$ & 0.910 & 0.906 & 0.027 & 33.935 \\
\hline KI5 & 0.728 & 0.727 & 0.074 & 9.806 \\
\hline KI6 & 0.795 & 0.782 & 0.056 & 14.227 \\
\hline \multicolumn{5}{|l|}{ Kul_Pel } \\
\hline KP1 & 0.777 & 0.764 & 0.069 & 11.297 \\
\hline KP2 & 0.899 & 0.898 & 0.025 & 35.549 \\
\hline KP3 & 0.518 & 0.500 & 0.162 & 3.194 \\
\hline KP4 & 0.851 & 0.851 & 0.032 & 26.195 \\
\hline \multicolumn{5}{|c|}{ Kep_Pem } \\
\hline US1 & 0.957 & 0.953 & 0.018 & 53.922 \\
\hline US2 & 0.966 & 0.965 & 0.011 & 86.890 \\
\hline US3 & 0.953 & 0.950 & 0.015 & 63.485 \\
\hline \multicolumn{5}{|c|}{ Net Benefit } \\
\hline NB1 & 0.864 & 0.861 & 0.034 & 25.189 \\
\hline NB10 & 0.322 & 0.313 & 0.144 & 2.240 \\
\hline NB2 & 0.876 & 0.880 & 0.027 & 32.191 \\
\hline NB3 & 0.834 & 0.838 & 0.064 & 12.998 \\
\hline NB4 & 0.762 & 0.742 & 0.074 & 10.253 \\
\hline NB5 & 0.770 & 0.738 & 0.091 & 8.488 \\
\hline NB6 & 0.858 & 0.847 & 0.044 & 19.333 \\
\hline NB7 & 0.768 & 0.761 & 0.074 & 10.326 \\
\hline NB8 & 0.488 & 0.485 & 0.113 & 4.316 \\
\hline NB9 & 0.345 & 0.324 & 0.161 & 2.148 \\
\hline
\end{tabular}

Sumber : hasil olah data

Berdasarkan tabel pada outer loading, indikator KS5 dengan nilai 0.592, KP3 dengan 
nilai 0.518, NB8 dengan nilai 0.488 , NB9 dengan nilai 0.345 dan NB10 dengan nilai 0.322 dikeluarkan dari model karena memiliki loading kurang dari 0.70 dan tidak signifikan.

Tabel 9

Result for outer loading

\begin{tabular}{|c|c|c|c|c|}
\hline & $\begin{array}{c}\text { Original } \\
\text { Sample }\end{array}$ & $\begin{array}{c}\text { Sample } \\
\text { Mean }\end{array}$ & $\begin{array}{c}\text { Standard } \\
\text { Deviation }\end{array}$ & T Statistics \\
\hline Kul_Sis & & & & \\
\hline KS1 & 0,821 & 0,823511 & 0,026904 & 30,522 \\
\hline KS2 & 0,812 & 0,813 & 0,029 & 27,679 \\
\hline KS3 & 0,783 & 0,787 & 0,028 & 27,915 \\
\hline KS4 & 0,797 & 0,798 & 0,025 & 32,398 \\
\hline KS6 & 0,823 & 0,822 & 0,027 & 30,425 \\
\hline KS7 & 0,727 & 0,715 & 0,045 & 16,136 \\
\hline Kul_Inf & & & & \\
\hline KI1 & 0,866 & 0,868 & 0,012 & 73,377 \\
\hline KI2 & 0,862 & 0,860 & 0,017 & 50,776 \\
\hline KI3 & 0,920 & 0,919 & 0,009 & 99,511 \\
\hline KI4 & 0,910 & 0,910 & 0,011 & 81,005 \\
\hline KI5 & 0,728 & 0,722 & 0,034 & 21,527 \\
\hline KI6 & 0,795 & 0,790 & 0,025 & 32,150 \\
\hline Kul_Pel & & & & \\
\hline KP1 & 0,795 & 0,798 & 0,035 & 22,468 \\
\hline KP2 & 0,921 & 0,921 & 0,009 & 97,039 \\
\hline KP4 & 0,839 & 0,842 & 0,017 & 48,234 \\
\hline Kep_Pem & & & & \\
\hline US1 & 0,957 & 0,958 & 0,007 & 133,947 \\
\hline US2 & 0,966 & 0,966 & 0,005 & 181,039 \\
\hline US3 & 0,953 & 0,953 & 0,009 & 106,523 \\
\hline Net Benefit & & & & \\
\hline NB1 & 0,883 & 0,882 & 0,010 & 88,427 \\
\hline NB2 & 0,897 & 0,899 & 0,008 & 107,872 \\
\hline NB3 & 0,849 & 0,850 & 0,029 & 29,039 \\
\hline NB4 & 0,793 & 0,792 & 0,034 & 23,532 \\
\hline NB5 & 0,783 & 0,779 & 0,035 & 22,379 \\
\hline NB6 & 0,858 & 0,855 & 0,017 & 49,534 \\
\hline NB7 & 0,741 & 0,739 & 0,038 & 19,271 \\
\hline
\end{tabular}

Sumber : hasil olah data

Berdasarkan perhitungan ulang dapat dilihat pada tabel diatas bahwa loading factor dari indikator - indikator di atas sudah memiliki nilai yang signifikan yaitu loading lebih dari 0.7.

\section{Pengujian Model Struktural}

Hasil pengujian terhadap hipotesis yang diajukan dapat dilihat dari koefisien inner weight PLS. Nilai inner weight PLS diterima jika signifikan terhadap 0.05 atau 1.96
Tabel 10

Hasil Result for Inner Weight

\begin{tabular}{|c|c|c|}
\hline & $\begin{array}{c}\text { original sample } \\
\text { estimate }\end{array}$ & T-Statistic \\
\hline Kul_Sis -> Kep_Pem & 0.027 & 0.305 \\
\hline Kul_Inf -> Kep_Pem & 0.404 & 5.851 \\
\hline Kul_Pel -> Kep_Pem & 0.466 & 6.670 \\
\hline Kep_Pem -> Net Benefit & 0.608 & 15.786 \\
\hline
\end{tabular}

Sumber : hasil olah data

Berdasarkan tabel hasil inner model (hubungan antar konstruk) kualitas sistem terhadap kepuasan pemakai menunjukkan koefisien parameter 0,027 dan nilai t-statistic 0,305 . Dikarenakan nilai t-statistik $(0,305)$ lebih kecil dari t-tabel $(1,64)$ maka $\mathrm{H} 1$ yang menyatakan bahwa kualitas sistem berpengaruh positif terhadap kepuasan pemakai hasilnya dinyatakan tidak signifikan. Artinya adalah kualitas sistem tidak berpengaruh positif langsung terhadap kepuasan pemakai menggunakan SIMRS. Sedangkan hasil dari pengujian koefisien parameter menunjukkan adanya korelasi yang positif $(0,027)$ antara konstruk kualitas sistem dengan konstruk kepuasan pemakai. Hasil ini menunjukan adanya perbedaan dengan hasil penelitian yang dilakukan oleh Livari (2005) dan McGill et al (2003) yang menyatakan bahwa perceived system quality merupakan prediktor yang signifikan terhadap kepuasan pemakai.

\section{Pengaruh Kualitas Informasi Terhadap Kepuasan Pemakai}

Berdasarkan tabel hasil inner model (hubungan antar konstruk) kualitas informasi terhadap konstruk kepuasan pemakai menunjukkan koefisien parameter 0,404 dan nilai t-statistic sebesar 5,851. Dapat disimpulkan bahwa konstruk kualitas informasi hasilnya memiliki pengaruh positif dan signifikan terhadap konstruk kepuasan pemakai dikarenakan nilai t-statistic $(5,851)$ lebih besar dari nilai t-tabel $(1,64)$. Sedangkan hasil dari koefisien parameter 
juga menunjukkan adanya korelasi yang positif $(0,404)$ antara kualitas informasi dengan kepuasan pemakai. Hasil ini menunjukkan bahwa konstruk kualitas informasi merupakan prediktor yang baik terhadap konstruk kepuasan pemakai. Hasil dari hipotesis ini sesuai dengan hasil penelitian yang dilakukan oleh Livari (2005) dan McGill (2003) yang menyatakan bahwa konstruk kualitas informasi memiliki pengaruh yang signifikan terhadap kepuasan pemakai.

Hasil penghitungan inner model (hubungan antar konstruk) menunjukkan bahwa pengaruh konstruk kualitas pelayanan terhadap kepuasan pemakai memiliki koefisien parameter 0,466 dan nilai t-statistic sebesar 6,670 . Berdasarkan hasil tersebut dapat disimpulkan bahwa konstruk kualitas pelayanan hasilnya berpengaruh signifikan positif terhadap konstruk kepuasan pemakai dengan nilai statistic $(6,670)$ lebih besar dari nilai t-tabel $(1,64)$. Sedangkan hasil dari koefisien parameter menunjukkan adanya korelasi positif $(0,466)$ antara kualitas pelayanan dengan kepuasan pemakai. Berdasarkan hasil tersebut dapat disimpulkan bahwa konstruk kualitas pelayanan merupakan salah satu prediktor yang baik yang mana konstruk tersebut memiliki pengaruh yang positif terhadap konstruk kepuasan pemakai. Hipotesis ini sesuai dengan yang pernah dilakukan oleh DeLone and McLean (2003) yang menambahkan konstruk kualitas pelayanan dalam suatu model untuk mengukur kesuksesan sistem teknologi informasi.

Berdasarkan hasil tabel inner model (hubungan antar konstruk) menunjukkan bahwa konstruk kepuasan pemakai sistem hasilnya signifikan positif terhadap variabel manfaatmanfaat bersih (net benefits) sebesar 15,786 lebih dari nilai t-tabel yaitu sebesar 1,64. Sedangkan hasil koefisien parameter yaitu sebesar 0,608 dapat disimpulkan bahwa setiap kepuasan yang dirasakan oleh setiap pemakai akan dapat mempengaruhi secara positif terhadap manfaatmanfaat baik bagi individu, grup/kelompok, organisasi maupun secara industri. Hipotesis ini sesuai dengan penelitian yang dilakukan oleh DeLone and McLean (2003) terhadap model kesuksesan sistem teknologi infomasi yang telah diperbaharui.

Sedangkan hasil evaluasi untuk pengujian $\mathrm{R}$-square dan Q-square dengan menggunakan software SmartPLS sebagai berikut:

\section{Tabel 11}

\section{$R$-square dan $Q$-square}

\begin{tabular}{|l|c|c|}
\hline & R-square & Q-square \\
\hline Kualitas Sistem & & \\
\hline Kualitas Informasi & & \\
\hline Kualitas Pelayanan & & \\
\hline Kepuasan Pemakai & 0,711 & 0,484 \\
\hline Net Benefit & 0,370 & 0,236 \\
\hline
\end{tabular}

Sumber : hasil olah data

Berdasarkan tabel diatas dapat disimpulkan bahwa nilai R-square untuk kepuasan pemakai adalah 0,711 yang artinya adalah variansi pada konstruk kepuasan pemakai dapat dijelaskan oleh konstruk kualitas sistem, kualitas informasi dan kualitas pelayanan sebesar $71,1 \%$ sedangkan $28,9 \%$ dijelaskan oleh variabel lain di luar konstruk. Sedangkan nilai R-square untuk Net Benefit adalah 0,370 dapat diartikan bahwa variansi konstruk manfaat-manfaat bersih (net benefit) dapat dijelaskan oleh konstruk kepuasan pemakai sebesar 37\% sedangkan $63 \%$ dijelaskan oleh variabel lain di luar konstruk.

Selain diperoleh hasil R-square, pada tabel juga terdapat hasil Q-square. Dari hasil tersebut dapat diinterpretasikan bahwa nilai Q-square untuk konstruk kepuasan pemakai dan manfaat-manfaat bersih (net benefit) adalah 0,484 dan 0,236 memiliki nilai yang lebih besar dari 0 (nol). Hal ini dapat disimpulkan bahwa model ini memiliki nilai predictive relevance. 


\section{KESIMPULAN DAN SARAN}

\section{Kesimpulan}

Penelitian ini bertujuan untuk menganalisis implementasi sistem informasi pada perusahaan jasa yang dalam hal ini adalah Rumah Sakit Khusus Bedah AN NUR Yogyakarta dengan menggunakan beberapa variabel atau konstruk yang terdapat di dalam model kesuksesan sistem DeLone dan McLean yang telah diperbaharui (2003). Variabel yang digunakan dalam penelitian ini adalah variabel eksogen yaitu kualitas sistem (system quality), kualitas informasi (information quality), dan kualitas pelayanan (service quality). Sedangkan variabel endogennya adalah kepuasan pemakai (users satisfaction) dan manfaatmanfaat bersih (net benefits). Alat analisis yang digunakan adalah SEM (Structural Equation Model) dengan menggunakan program SmartPLS versi 2.0 dengan pengamatan sampel sebanyak 50 kuesioner.

Berdasarkan hasil analisis data dan pengujian hipotesis, maka dapat ditarik kesimpulan sebagai berikut:

1. Kualitas sistem (system quality) mempunyai korelasi yang positif akan tetapi tidak signifikan terhadap kepuasan pemakai (users satisfaction). Korelasi positif itu menggambarkan bahwa semakin baik kualitas sistem yang ada maka akan meningkatkan kepuasan para pemakainya. Akan tetapi hasil dari penelitian ini menunjukkan bahwa kualitas sistem belum mencerminkan dengan baik kepuasan yang diharapkan oleh pemakai sistem. Kualitas sistem yang dihasilkan oleh SIMRS yang meliputi keandalan, kemudahan akses, kecepatan merespon, kemudahan penggunaan, keamanan data, realisasi kebutuhan pemakai dan kenyamanan mengakses sistem dimungkinkan belum bisa merepresentasikan harapan para pemakai sistem sehingga berpengaruh kepada kepuasan para pemakainya.
Oleh karena itu, diharapkan kepada manajemen khususnya untuk bagian Teknologi Informasi (TI) dapat dijadikan sebagai bahan evaluasi untuk meningkatkan kualitas sistem SIMRS dengan memasukkan indikatorindikator kualitas sistem yang sesuai dengan harapan pemakai (karyawan).

2. Kualitas informasi (information quality) mempunyai korelasi positif dan signifikan terhadap kepuasan pemakai (users satisfaction). Korelasi positif antar konstruk tersebut menggambarkan bahwa semakin baik kualitas informasi yang dihasilkan oleh sistem tersebut maka akan semakin tinggi pula kepuasan pemakainya. Jika kualitas informasi yang dihasilkan oleh SIMRS akurat, relevan, update, lengkap, jelas dan mudah dimengerti maka para pemakai SIMRS akan merasa puas dalam menggunakan sistem. Hasil penelitian ini sejalan dengan penelitian yang dilakukan oleh DeLone dan McLean (1992) bahwa kualitas informasi (information quality) suatu sistem dapat mempengaruhi kepuasan pemakai (users satisfaction). Dari hasil ini dapat diperkirakan bahwa menurut para pemakai, kualitas sistem yang dihasilkan oleh SIMRS telah sesuai dengan yang diinginkan. Akan tetapi untuk lebih dapat meningkatkan kualitas informasi maka diharapkan manajemen rumah sakit AN NUR lebih memperhatikan hasil output SIMRS dan meminimalisir agar tidak sering terjadi gangguan dalam server.

3. Kualitas pelayanan (service quality) berkorelasi positif dan signifikan terhadap kepuasan pemakai (users satisfaction). Berdasarkan hasil tersebut, dapat disimpulkan bahwa kualitas pelayanan yang diberikan kepada para pemakai SIMRS dalam hal ini adalah bagian IT telah sesuai dengan yang diharapkan sehingga kepuasan pemakai SIMRS tinggi. Hasil penelitian ini sesuai dengan konsep model kesuksesan sistem informasi DeLone 
dan McLean yang telah diperbaharui (2003) dimana model ini memisahkan konstruk kualitas pelayanan dari kualitas sistem. Kualitas pelayanan pada penelitian ini menggunakan indikator responsiveness, assurance, emphaty dan realibility sebagai indikator pengukurannya terhadap kepuasan pemakai.

4. Kepuasan pemakai (users satisfaction) berkorelasi positif dan signifikan terhadap manfaat-manfaat bersih (net benefits). Semakin tinggi kepuasan yang dirasakan oleh para pemakai SIMRS maka akan berdampak pada manfaat-manfaat yang akan diperoleh bagi individu pemakai sistem sendiri, grup atau unit pemakai dan juga bagi organisasi dimana pemakai SIMRS bekerja. Oleh karena itu, untuk dapat mempertahankan dan meningkatkan manfaat-manfaat bersih (net benefits) manajemen Rumah Sakit AN NUR diharapkan dapat lebih memperhatikan terhadap saran dan masukan dari para karyawan terkait dengan kepuasan yang dirasakan oleh para pemakai SIMRS. Hasil penelitian ini sesuai dengan penelitian yang dilakukan oleh DeLone dan McLean dan juga beberapa peneliti lainnya yang memberikan kesimpulan bahwa kepuasan pemakai sistem merupakan prediktor yang sangat penting dan selalu memiliki korelasi dengan net benefits.

Penelitian ini mengandung beberapa keterbatasan, antara lain:

1. Konstruk kualitas sistem tidak menggunakan indikator-indikator yang baik dalam mengukur pengaruh kualitas sistem terhadap kepuasan pemakai. Hal ini menyebabkan hasil yang diperoleh tidak sesuai yang diharapkan penulis karena adanya kemungkinan indikator-indikator tersebut kurang mencerminkan kondisi riil dengan yang ada di objek penelitian.
2. Sampel penelitian yang digunakan dalam penelitian hanya sebatas pemakai sistem yang menggunakan secara langsung dan intens tidak termasuk pemakai hasil dari penggunaan sistem tersebut yang dalam hal ini adalah para pasien. Hal ini menyebabkan sampel yang digunakan hanya sedikit.

3. Kemungkinan adanya kesalahan intepretasi terhadap pertanyaan-pertanyaan kuesioner sehingga menimbulkan kesalahpahaman responden dalam menjawab pertanyaan kuesioner. Selain itu, kesibukan pekerjaan yang dilakukan oleh responden menimbulkan ketidakkonsistenan responden dalam menjawab kuesioner.

\section{Saran}

Saran yang didasarkan pada beberapa keterbatasan penelitian adalah sebagai berikut:

1. Penelitian mendatang sebaiknya menggunakan indikator-indikator yang lebih mencerminkan keadaan sesungguhnya sehingga didapat hasil yang lebih riil.

2. Dalam penelitian ini telah menghapuskan konstruk penggunaan / intensitas penggunaan (use) dikarenakan penelitian ini menggunakan objek penelitian sistem secara mandatory. Rekomendasi untuk penelitian yang akan datang adalah jika objek penelitian menggunakan sistem yang mandatory maka sebaiknya konstruk penggunaan (use) dapat dihilangkan dari model penelitian akan tetapi jika menggunakan objek penelitian sistem voluntary maka konstruk penggunaan harus tetap dimasukkan ke dalam model penelitian.

3. Rekomendasi bagi penelitian yang akan datang adalah memperluas cakupan responden yang digunakan. Responden dapat mencakup para pemakai hasil SIMRS yang dalam hal ini adalah para pasien yang telah menerima bukti rincian biaya perawatan dan juga para pemakai sistem yang berada di rumah sakit lainnya. 
4. Penelitian yang akan datang diharapkan dapat meningkatkan kualitas bahasa yang digunakan dalam pertanyaan-pertanyaan kuesioner sehingga akan dapat memudahkan responden dalam menjawab pertanyaan. Selain itu dalam pengisian kuesioner diusahakan dilakukan pada saat responden berada pada waktu yang senggang sehingga tidak mempengaruhi jawaban yang diberikan.

\section{DAFTAR PUSTAKA}

Budianto, 2009. Evaluasi Kesuksesan Sistem Informasi dengan Pendekatan Model DeLone and McLean (Studi Kasus Implementasi Billing System di RSUD Kabupaten Sragen) Tesis Program Pasca Sarjana. Fakultas Ekonomi Universitas Sebelas Maret. Surakarta

Chin, W. W. 1998. "The Partial Least Squares Approach to Structural Equation Modeling", in Marcoulides, G.A (ed), Modern Methods for Business Research, Mahwah, NJ: Lawrence Erlbaum Associated, pp. 295-336

Cooper, Donald R. and Pamela S. Schindler. 2006. Business Research Methods, 9th ed., New York, NY: Irwin / McGrawHill

DeLone, W. H., dan McLean, E.R. 1992. "Information Systems Success: The Quest for the Dependent Variable," Information Systems Research, (3:1), pp. $60-95$

DeLone, W. H., \& McLean, E. R (2002, jan). Information Systems Success Revised. Proceedings of the 35th Annual hawai International Conference on System Sciences, IEEE Computer Society, Hawai, HI

DeLone, W. H., \& McLean, E. R. (2003). "The DeLone and McLean Model of
Information Systems Success: A Ten Year Update." Journal of management Information Systems, 19(4), 9-30

Dody Radityo dan Zulaikha, 2007, Pengujian model DeLone and McLean dalam Pengembangan Sistem Informasi Manajemen”, Simposium Nasional Akuntansi $\mathrm{X}$

Ghozali, I. 2005, Aplikasi Analisis Multivariat dengan Program SPSS, Semarang: Badan Penerbit Universitas Diponegoro.

Hammer, Lyn. 2004. Assessment of Success of a Computerised Hospital Information System in a Public Sector Hospital in South Africa

Ives, B., \& Olson, M. 1984. "User Involvement and MIS Success: A Review of Research." Management Science, 30(5), 586-603

Janson, M. A., and Subramanian, A. 1996. Packaged Software: Selection and Implementation policies. INFOR 34(2), 133-151

Jogiyanto. 2007,"Model Kesuksesan Sistem Teknologi Informasi" ANDI Yogyakarta

Jogiyanto. 2009."Konsep \& Aplikasi PLS (Partial Least Square) untuk Penelitian Empiris", ANDI Yogyakarta

Lin, H. F. 2007, Measuring Online Learning System Success: Applying the Updated DeLone and McLean Model, Cyber Psychology \& Behaviour, 10:6, 817-820

Livari, Juhani. 2005, An Empirical Test of DeLone-McLean Model of Information System Success. Database of Advance in Information System

Lucas, H.C. Jr. 1981, "An Experiment Investigation of The Use of ComputerBased Graphilies in Decision-Making." Management Science (27;7), Juli, pp. $757-768$

Lucas, H. C., Jr. Walton, E. J., dan Ginzberg, M. J. 1988, Implementing Packaged Software, MIS Quartely 
Malhotra, N.K. 1999, Marketing Research: An Aplied Orientation, 3th ed., New Jersey: Prentice Hall International, Inc

Molla, A., dan Licker, P.S. 2001 "E-commerce Systems Success: an Attempt to Extend and Respecify the DeLone and McLean model of ISS." Journal of Electronic Commerce Research, (2:4), pp. 1-11

Mithas, S et al. 2007, Information Technology Infrastructure Capability and Firm Performance; An Empirical Analysis

Nelson, K., \& Somers, T 2001. Exploring ERP Success from an End-User Perspective. Paper presented at the Americans Conference on Information Systems (AMCIS)

Pitt, L. F., Watson, R. T., \& Kavan, B. 1995, Service Quality: A Measure of Information Systems Effectiveness. MIS Quartely, 19(2), 173-187

Radityo, Dody \& Zulaikha, 2007. Pengujian Model DeLone and McLean dalam Pengembangan Sistem Informasi Manajemen (kajian sebuah kasus). SNA X. Makasar
Sabherwal, R., Jeyaraj, A., \& Chowa, C. 2006. Information System Success: Individual and Organizational Determinants, Management Sciences, 52 (12), 1849 1864

Salisbury, W.D., Chin, W.W., Gopal, A. And Newsted, P.R. 2002. Research report: Better theory through measurement developing a scale to capture consensus on appropiation. Information System Research, 13: 91-103

Seddon, P. B., and Kiew, M.Y., A Partial Test and Development of the DeLone and McLean Model of IS Success, Information Systems Research, 240-253

Seddon, P. B. 1997. A Respecification and Extension of the DeLone and McLean Model of IS Success. Information Systems Research, 8(3), 240

Wiyono, Adrianto S., Hartono, Jogiyanto, Ancok, Djamaludin, 2008. Aspek Psikologis pada Implementasi Sistem Teknologi Informasi, makalah dalam Seminar e-Indonesia Initiative 2008 (eII2008), Konferensi dan Temu Nasional Teknologi Informasi dan Komunikasi untuk Indonesia. Jakarta 